\title{
FURTHER STUDIES ON AN ASPOROGENOUS MUTANT OF BACILLUS SUBTILIS LACKING IN VIVO PROTEOLYTIC ACTIVITY
}

\author{
MASATAKA NAKAMURA, ${ }^{1}$ SUMIO OKAMURA, ${ }^{2}$ \\ KAZUO IZAKI, AND HAJIME TAKAHASHI \\ Department of Agricultural Chemistry, Faculty of Agriculture, \\ Tohoku University, Sendai 980
}

(Received November 28, 1979)

\begin{abstract}
Various properties such as $\mathrm{pH}$ optimum, response to metal ions and inhibitors, and heat stability of two extracellular and one intracellular proteases from both parent and asporogenous strains of Bacillus subtilis were examined, and no significant difference between the two strains was observed. The intracellular protease was shown to be a serine protease absolutely requiring $\mathrm{Ca}^{2+}$. We examined in vivo degradation of the cellular protein at the stationary phase in both parent and mutant strains and found that degradation occurred only in the parent strain. Addition of $\mathrm{Ca}^{2+}$ and toluene together to the reaction mixture of the mutant strain, however, resulted in significant degradation of the cellular protein in the mutant strain, although the addition of either $\mathrm{Ca}^{2+}$ or toluene alone had no stimulating effect on the degradation. These results suggest that the mutant strain is defective in its transport system for $\mathrm{Ca}^{2+}$.
\end{abstract}

We previously isolated an early-blocked asporogenous mutant of Bacillus subtilis Marburg, strain 61, (I) and we speculated that spore-type RNA polymerase did not function but that the vegetative RNA polymerase was active in this mutant from the measurement of protein and RNA synthesis of the mutant in both logarithmic and stationary phases $(1,2)$. We also found that the degradation of preformed proteins occurred in the parent strain during the stationary phase, while no significant degradation was observed in the mutant strain. Although serine and metal proteases were found in both the culture medium and the cell extracts, these proteases were not likely to function in the mutant in vivo during the stationary phase (3). In this study, we have tried to determine why intracellular protease

Present address: ${ }^{1}$ Department of Bacteriology, Tohoku University School of Medicine, Sendai 980.

2 Tagajo High School, Tagajo City 985, Miyagi. 
does not function in vivo in this mutant.

\section{MATERIALS AND METHODS}

Bacterial strains and media. Bacterial strains and media used throughout the experiment were the same as those described previously (1). Bacillus subtilis Marburg strain $111\left(\mathrm{leu}^{-}\right)$was the sporogenous strain, and strain $61\left(\mathrm{leu}^{-}\right)$was the asporogenous mutant derived from strain 111 by acriflavin treatment (1).

Chemicals. ${ }^{3} \mathrm{H}$-L-phenylalanine $(16.1 \mathrm{Ci} / \mathrm{mmole}),{ }^{14} \mathrm{C}$-L-phenylalanine $(418$ $\mathrm{mCi} / \mathrm{mmol})$ and ${ }^{45} \mathrm{CaCl}_{2}(20 \mathrm{mCi} / \mathrm{mg}$ of $\mathrm{Ca})$ were purchased from the New England Nuclear Corp., Boston. Azocasein, milk casein, diisopropylfluorophosphate (DFP) and phenylmethylsulfonylfluoride (PMSF) were obtained from Sigma Chemical Co., St. Louis.

Extracellular protease activity. A portion $(5 \mathrm{ml})$ of the culture fluid centrifuged at $8,000 \times g$ for 2 min was dialyzed against $0.05 \mathrm{M}$ Tris- $\mathrm{HCl}$ buffer $(\mathrm{pH} 7.3)$ for $24 \mathrm{hr}$. The protease activity of the dialyzed fluid was measured by the method of YASUNOBU et al. (4). To the supernatant $(0.5 \mathrm{ml})$ was added $0.05 \mathrm{M}$ Tris- $\mathrm{HCl}$ buffer $(1 \mathrm{ml}, \mathrm{pH} 7.3)$ and $0.6 \%$ milk casein solution $(1.5 \mathrm{ml}, \mathrm{pH} 7.3)$ and the reaction mixture was incubated for $10 \mathrm{~min}$ at $30^{\circ}$. The enzyme reaction was terminated by adding $2.5 \mathrm{ml}$ of the protein precipitation reagent $(0.11 \mathrm{M}$ trichloroacetic acid [TCA], $0.22 \mathrm{~m}$ sodium acetate and $0.33 \mathrm{~m}$ acetic acid). After the filtrate had stood for $2 \mathrm{hr}$ at $30^{\circ}$, its optical density was measured at $275 \mathrm{~nm}$. The readings were corrected for the values of blank tests, in which the enzyme solution was mixed with the precipitation reagent followed by the addition of the substrate. One unit of protease activity was defined as the amount of the enzyme which liberates a TCAsoluble digestion product equivalent to $1 \mu \mathrm{g}$ of tyrosine in $1 \mathrm{~min}$ at $30^{\circ}$.

Intracellular protease activity. Cells harvested by centrifugation at $8,000 \times g$ for $8 \mathrm{~min}$ were washed four times with $0.05 \mathrm{M}$ Tris- $\mathrm{HCl}$ buffer $(\mathrm{pH} \mathrm{7.3)}$ and resuspended in the same buffer. The cells were disrupted in a French pressure cell twice $\left(1,500 \mathrm{~kg} / \mathrm{cm}^{2}\right.$, Ohtake Works Co., Ltd., Tokyo) or with a Kubota sonic oscillator at $10 \mathrm{kHz}$ for $10 \mathrm{~min}$. In both cases, the insoluble debris was removed by centrifugation at $15,000 \times g$ for $20 \mathrm{~min}$ and the supernatant fluid was dialyzed against 200 volumes of the above buffer for $24 \mathrm{hr}$ at $4^{\circ}$ and used as the crude extract.

Intracellular protease activity was measured as follows. A portion $(0.5 \mathrm{ml})$ of the crude extract, which was diluted appropriately with $0.05 \mathrm{M}$ Tris- $\mathrm{HCl}$ buffer

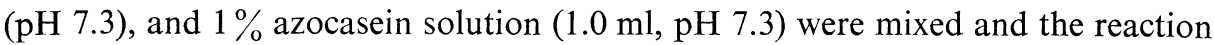
mixture was incubated for the desired time at $30^{\circ}$. The enzyme reaction was terminated by adding $1.5 \mathrm{ml}$ of $10 \%$ TCA and was kept for $1 \mathrm{hr}$ in ice water. Then the reaction mixture was filtered through a Toyo filter paper No. 5B. To the filtrate $(2 \mathrm{ml}), 1.5 \mathrm{ml}$ of $0.4 \mathrm{~N} \mathrm{NaOH}$ was added and the mixture was shaken vigorously. After the filtrate had stood for $1 \mathrm{hr}$ at room temperature, the optical 
density at $420 \mathrm{~nm}$ was measured (5).

Serine protease and metal protease activity. Serine protease activity was measured in the presence of $2.5 \mathrm{~mm}$ EDTA or $o$-phenanthroline, both of which are inhibitors of metal protease, while metal protease activity was measured in the presence of $3.6 \mathrm{~mm}$ DFP or $3.3 \mathrm{~mm}$ PMSF, which are inhibitors of serine protease. Protease and the inhibitor were incubated at $0^{\circ}$ for $1 \mathrm{hr}$ before addition of the substrate (5).

Protein measurements. Protein was determined by the method of LowRY et al. (6).

Preparation of Schaeffer's medium containing various concentrations of calcium ion. Meat extract was dialyzed against deionized water at $4^{\circ}$ for $72 \mathrm{hr}$ and was used as an ingredient of Schaeffer's medium. Various concentrations of $\mathrm{CaCl}_{2}$ were added to the Schaeffer's medium from which $\mathrm{CaCl}_{2}$ was originally omitted.

Labeling of the cells of the parent and mutant strains. Cells of the parent and mutant strains were grown to the mid-logarithmic phase in $100 \mathrm{ml}$ of Schaeffer's medium containing $20 \mu \mathrm{Ci}$ of ${ }^{14} \mathrm{C}$-L-phenylalanine and the same medium containing $80 \mu \mathrm{Ci}$ of ${ }^{3} \mathrm{H}$-L-phenylalanine. The cells were harvested, washed, sonicated, centrifuged, and dialyzed as described for the preparation of intracellular protease. Specific activity of the proteins was $1.1 \times 10^{5} \mathrm{dpm} / \mathrm{mg}$ of protein for the parent strain and $3.4 \times 10^{5} \mathrm{dpm} / \mathrm{mg}$ of protein for the mutant strain.

Assay of protease activity with labeled protein as substrate. The crude extract was prepared from the cells as described for the preparation of intracellular protease. The reaction mixture contained $240 \mu \mathrm{l}$ of the crude extract and $240 \mu \mathrm{l}$ of the labeled protein substrate. $\mathrm{CaCl}_{2}$ was added at a final concentration of $2 \mathrm{~mm}$. Incubation was carried out at $30^{\circ}$ and a portion of the reaction mixture $(80 \mu \mathrm{l})$ was removed after various periods of incubation and was added to $100 \mu \mathrm{l}$ of $10 \%$ cold TCA. After standing for $12 \mathrm{hr}$ in ice water, the reaction mixture was filtered through a glass filter (Toyo Roshi GC-50). The precipitates on the filter were washed with $10 \mathrm{ml}$ of $10 \%$ cold TCA and then $5 \mathrm{ml}$ of ethanol. The filter was dried and placed in $10 \mathrm{ml}$ of toluene-Nonione scintillation fluid (7) from which POPOP was omitted, and the radioactivity was determined with a liquid scintillation spectrometer (Tri-Carb model 3385, Packard).

Accumulation of ${ }^{45} \mathrm{Ca}$ in the cells of the parent and mutant strains. Bacteria were grown aerobically at $30^{\circ}$ in Schaeffer's medium containing $100 \mu \mathrm{Ci}$ of ${ }^{45} \mathrm{CaCl}_{2}$ per $\mathrm{ml}$. After various periods of incubation, two samples $(0.5 \mathrm{ml}$ each) were taken from the shaking flask; one was put directly into the counting vial and the other was filtered through a membrane filter (type-HA, Millipore) and washed with cold Schaeffer's medium and the filter was placed in the vial. Toluene-Nonione scintillation fluid $(9.5 \mathrm{ml})$ as described above was added to each vial and the radioactivity was counted as described above.

Assay of protein degradation in buffer. The cells of the parent and mutant strains were grown for $11 \mathrm{hr}$ at $30^{\circ}$ in $100 \mathrm{ml}$ of Schaeffer's medium containing 
$1 \mu \mathrm{Ci}$ of ${ }^{3} \mathrm{H}-\mathrm{L}$-phenylalanine, harvested at $8,000 \times g$ for $8 \mathrm{~min}$, washed three times with $0.05 \mathrm{M}$ Tris- $\mathrm{HCl}$ buffer ( $\mathrm{pH} \mathrm{7.3)}$ and suspended in $10 \mathrm{ml}$ of the same buffer at $4^{\circ}$. The cells were incubated with or without $2 \mathrm{mM} \mathrm{CaCl}_{2}$. The effect of toluene at a final concentration of $1 \%$ was also examined. Portions $(0.5 \mathrm{ml})$ of the incubation mixture were removed after various periods of incubation and added to an equal volume of $10 \%$ cold TCA. After standing in ice water overnight, the precipitate was collected on the glass filter and washed with $10 \%$ cold TCA and ethanol and its radioactivity was counted as described above.

\section{RESULTS}

Production of extracellular and intracellular proteases of the parent and mutant strains

Figure 1 shows the time course of the secretion of the proteases into the medium by the parent and asporogenous mutant strains. The parent strain began to sporulate after about $16 \mathrm{hr}$ of cultivation and the sporulation was almost complete at $26 \mathrm{hr}$. Both strains began to produce proteases in about the same growth phase, $T_{3}$. The asporogenous mutant strain secreted about twice as much as the parent strain. Serine protease activity was much higher than metal protease activity in both parent and mutant strains, being responsible for approximately $80 \%$ of the total activity. Intracellular protease appeared in phase $T_{0}$, as shown in Fig. 2, and the activity became maximal in about phases $T_{3}$ and $T_{4}$. The asporogenous mutant strain produced 1.3 times as much intracellular protease as the parent strain at the peak of production. Table 1 shows the activity of both intracellular and extracellular proteases in the presence of various inhibitors.

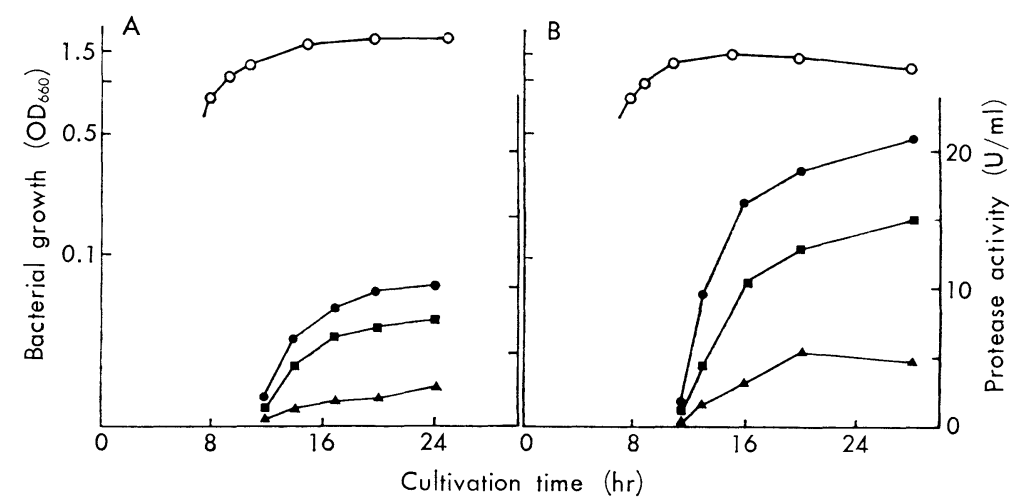

Fig. 1. Protease secretion into medium by the parent (A) and the mutant (B) strains.

Total protease, serine protease and metal protease activity was assayed in the presence of $2 \mathrm{mM} \mathrm{CaCl}_{2}$, in the absence of $\mathrm{CaCl}_{2}$ and in the presence of $2 \mathrm{mM} \mathrm{CaCl}$, respectively. $\mathrm{O}$, Growth of bacteria; $\boldsymbol{\bullet}$, total protease activity; $\boldsymbol{\square}$, serine protease activity; $\boldsymbol{\Lambda}$, metal protease activity. 


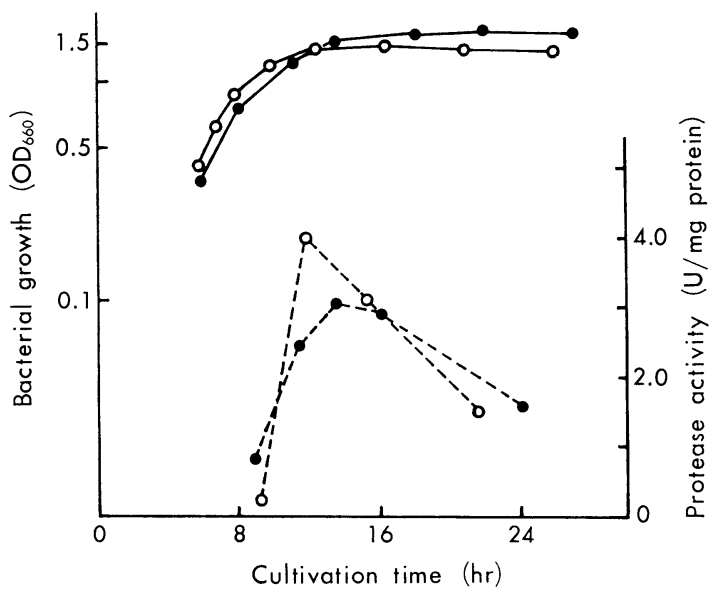

Fig. 2. Kinetics of the intracellular protease formation of the parent and mutant strains during the stationary phase.

The enzyme activity was assayed in the presence of $2 \mathrm{mM} \mathrm{CaCl}_{2}$. - - growth of the parent strain; - - - growth of the mutant strain; ---๑--- parent protease activity; ----- mutant protease activity.

\section{Properties of extracellular and intracellular proteases}

Extracellular proteases: Activity of metal protease, which was measured in the presence of $2 \mathrm{mM} \mathrm{Ca}^{2+}$ and $3.6 \mathrm{mM}$ DFP or $3.3 \mathrm{mM}$ PMSF, was $20-25 \%$ of the total activity, while no activity was observed when $2 \mathrm{mM} \mathrm{Ca}^{2+}$ was omitted from the incubation mixture. These results indicate that metal protease measured under these conditions requires $\mathrm{Ca}^{2+}$ for activity. On the other hand, serine protease activity, which could be measured in the presence of $2.5 \mathrm{~mm}$ EDTA or $o$-phenanthroline, showed nearly the same activity in the absence of $\mathrm{Ca}^{2+}$. The percentage of serine protease or metal protease is similar in the parent and mutant strains as shown by MiLlet (5).

Intracellular protease: As shown in Table 1, the protease activity in the absence of $\mathrm{Ca}^{2+}$ is just as strong as the protease activity in the presence of EDTA or $o$-phenanthroline; therefore, intracellular serine protease seems to require $\mathrm{Ca}^{2+}$ for its activity. This property is different from that of extracellular serine protease. The protease activity in the presence of DFP or PMSF and $\mathrm{Ca}^{2+}$, which represents metal protease activity, was less than one-tenth of the total activity in the presence of $\mathrm{Ca}^{2+}$; therefore, most of the intracellular protease activity is explained by serine protease in both parent and mutant strains. Effects of inhibitors on intracellular proteases were similar in the parent and mutant strains.

The effects of various metal ions on intracellular and extracellular proteases were examined. As shown in Table 2, no absolute requirement for metal ion was observed with the extracellular serine proteases. Only $\mathrm{Ca}^{2+}$ stimulated and only 
Table 1. Effect of calcium ion and inhibitors on protease activity.

\begin{tabular}{lcccc}
\hline \multirow{2}{*}{$\begin{array}{c}\text { Inhibitor and metal ion } \\
\text { added }\end{array}$} & \multicolumn{2}{c}{ extracellular } & \multicolumn{2}{c}{ Relative activity of } \\
\cline { 2 - 5 } & Parent & Mutant & Parent & Mutant \\
\hline $\mathrm{Ca}^{2+}$ & 100 & 100 & 100 & 100 \\
$\mathrm{None}_{\text {DFP, } \mathrm{Ca}^{2+}}$ & 78.5 & 83.2 & 9.0 & 10.0 \\
PMSF, Ca & 22.0 & 25.3 & 7.3 & 8.0 \\
DFP & 24.6 & 25.5 & 6.4 & 6.0 \\
PMSF & 3.0 & 4.3 & 6.5 & 5.6 \\
EDTA & 1.6 & 2.0 & 6.3 & 6.5 \\
$o$-Phenanthroline & 74.2 & 72.5 & 10.0 & 8.9 \\
PMSF, EDTA & 79.0 & 80.6 & 8.3 & 7.8 \\
\hline
\end{tabular}

The extracellular protease activity of the parent and the mutant strains in the presence of $2 \mathrm{mM} \mathrm{CaCl}_{2}$ was $9.8 \mathrm{U} / \mathrm{ml}$ and $18.4 \mathrm{U} / \mathrm{ml}$, respectively. The intracellular protease activity of the parent and the mutant strains in the presence of $2 \mathrm{mM} \mathrm{CaCl}_{2}$ was $2.3 \mathrm{U} / \mathrm{mg}$ of protein and $2.8 \mathrm{U} / \mathrm{mg}$ of protein, respectively. DFP, PMSF, EDTA, o-phenanthroline and $\mathrm{CaCl}_{2}$ were used at concentrations of $3.6 \mathrm{~mm}, 3.3 \mathrm{~mm}, 2.5 \mathrm{~mm}, 2.5 \mathrm{~mm}$ and $2 \mathrm{~mm}$, respectively.

Table 2. Effect of various metal ions on protease activity.

\begin{tabular}{|c|c|c|c|c|c|c|}
\hline \multirow{3}{*}{$\begin{array}{c}\text { Metal ion } \\
\text { added (mM) }\end{array}$} & \multicolumn{2}{|c|}{ intracellular } & \multicolumn{4}{|c|}{ extracellular } \\
\hline & \multirow{2}{*}{ Parent } & \multirow{2}{*}{ Mutant } & \multicolumn{2}{|c|}{ Metal protease } & \multicolumn{2}{|c|}{ Serine protease } \\
\hline & & & Parent & Mutant & Parent & Mutant \\
\hline $\mathrm{Ca}^{2+}(2)$ & 100 & 100 & 100 & 100 & 100 & 100 \\
\hline None & 5.5 & 9.9 & 0.0 & 3.6 & 75.0 & 86.6 \\
\hline $\mathrm{Mg}^{2+}(2)$ & 4.0 & 7.4 & 94.0 & 95.5 & 81.8 & 92.6 \\
\hline $\mathrm{Ni}^{2+} \quad(1)$ & 9.1 & 10.3 & 1.4 & 7.9 & 69.3 & 58.5 \\
\hline $\mathrm{Zn}^{2+} \quad(1)$ & 8.6 & 7.6 & 96.7 & 98.8 & 73.3 & 68.9 \\
\hline $\mathrm{Mn}^{2+}(1)$ & 3.5 & 2.8 & 88.9 & 94.3 & 71.0 & 60.5 \\
\hline $\mathrm{Co}^{2+}$ (1) & 2.7 & 2.1 & 0.0 & 0.0 & 0.0 & 0.0 \\
\hline $\mathrm{Sr}^{2+} \quad(1)$ & 9.8 & 9.6 & & & & \\
\hline
\end{tabular}

The intracellular and extracellular serine and extracellular metal protease activity of the parent strain in the presence of $2 \mathrm{mM} \mathrm{CaCl}_{2}$ was $2.2 \mathrm{U} / \mathrm{mg}$ of protein, $7.9 \mathrm{U} / \mathrm{ml}$ and $2.6 \mathrm{U} / \mathrm{ml}$, respectively. The intracellular and extracellular serine and extracellular metal protease activity of the mutant strain in the presence of $2 \mathrm{mM} \mathrm{CaCl}_{2}$ was $2.8 \mathrm{U} / \mathrm{mg}$ of protein, $12.8 \mathrm{U} / \mathrm{ml}$ and $4.1 \mathrm{U} / \mathrm{ml}$, respectively. All of the metal ions used were chloride salts.

$\mathrm{Co}^{2+}$ strongly inhibited the activity. Similar effects of metal ions on the serine proteases were observed both in parent and mutant strains. On the other hand, extracellular metal proteases required $\mathrm{Ca}^{2+}, \mathrm{Mg}^{2+}, \mathrm{Zn}^{2+}$, or $\mathrm{Mn}^{2+}$ for the activity, while $\mathrm{Co}^{2+}$ and $\mathrm{Ni}^{2+}$ had strong inhibitory effects. Again, no significant difference in response to various metal ions was found in the parent and mutant strains. As shown in Tables 1 and 2, almost all intracellular proteases were the serine pro- 
teases requiring $\mathrm{Ca}^{2+}$ since the activity was inhibited strongly by DFP or PMSF, and $\mathrm{Ca}^{2+}$ was specifically required for maximal activity. As shown in Table 2, no difference between parent and mutant strains in the responses of their intracellular proteases to metal ions was found.

\section{Effect of calcium concentration on intracellular serine protease}

Intracellular serine proteases from the parent and mutant strains possessed a similar requirement of $\mathrm{Ca}^{2+}$ for their activity (Fig. 3). These results are consistent with those obtained by ReYsSET and Millet (8).

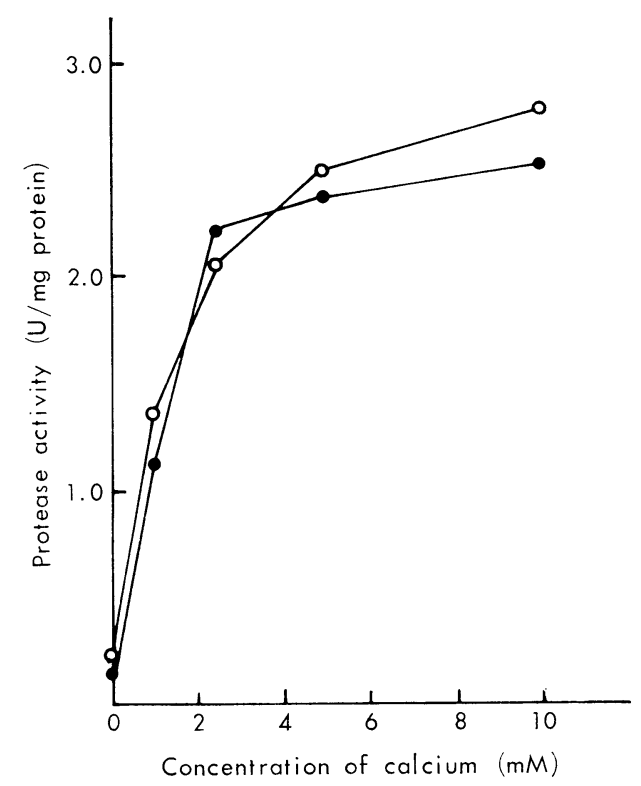

Fig. 3. Effect of calcium concentration on the intracellular protease activity.

The enzyme solutions of both parent and mutant strains were prepared from cells in the $T_{3}$ phase as described in MATERIALS AND METHODS. •, parent strain; $\bigcirc$, mutant strain.

\section{Effect of $\mathrm{pH}$ on intracellular protease activity}

The optimal $\mathrm{pH}$ of intracellular proteases of both parent and mutant strains were examined. Both strains had a rather broad optimal $\mathrm{pH}$ between 6.8 and 8.0 (Fig. 4). Extracellular serine proteases of the parent and mutant strains had a similar broad optimal $\mathrm{pH}$ between 6.8 and 8.0 , while extracellular metal proteases had a sharp optimal $\mathrm{pH}$ between 6.8-7.4 (data not shown).

\section{Heat stability of proteases}

The heat stability of intracellular proteases of both parent and mutant strains 


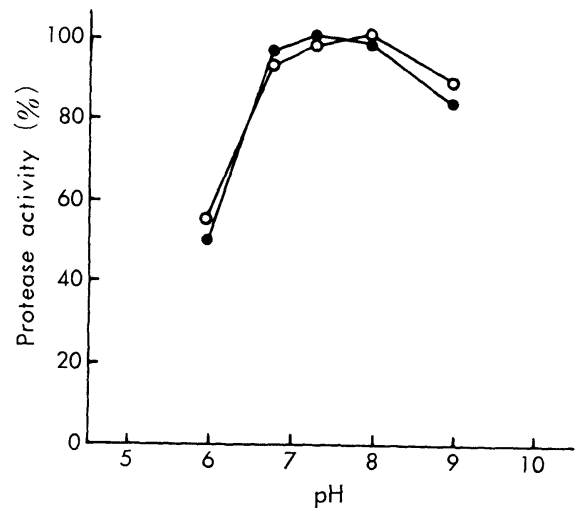

Fig. 4. Effect of $\mathrm{pH}$ on the intracellular protease activity of parent and mutant strains.

Five-hundredth molar sodium cacodylate buffer containing $2 \mathrm{mM} \mathrm{CaCl}_{2}$ and $0.05 \mathrm{M}$ Tris- $\mathrm{HCl}$ buffer containing $2 \mathrm{mM} \mathrm{CaCl}_{2}$ were used for the $\mathrm{pH}$ ranges of 6.0-7.2 and 7.29.0 , respectively. One hundred percent protease activity represented $2.2 \mathrm{U} / \mathrm{mg}$ of protein for the parent $(\bullet)$ and $2.8 \mathrm{U} / \mathrm{mg}$ of protein for the mutant strain $(\bigcirc)$ under the condition of $0.05 \mathrm{M}$ Tris- $\mathrm{HCl}$ buffer $\left(\mathrm{pH} 7.3\right.$ ) containing $2 \mathrm{~mm} \mathrm{CaCl}_{2}$.

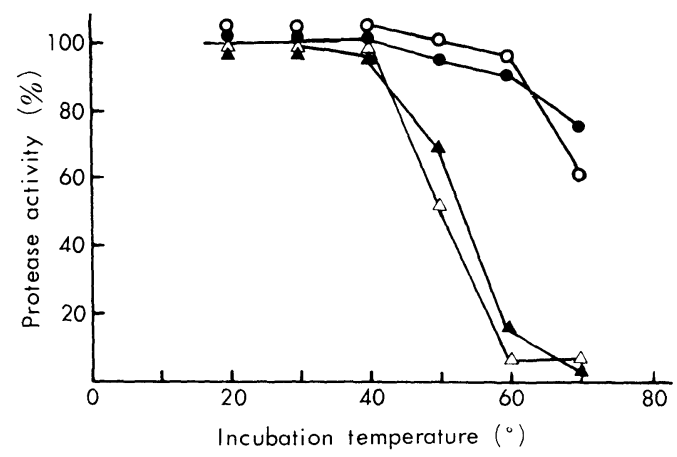

Fig. 5. Heat stability of the intracellular protease from the parent and mutant strains.

The enzyme solution was incubated for $8 \mathrm{~min}$ in the presence or absence of $2 \mathrm{~mm}$ $\mathrm{CaCl}_{2}$ at the temperature indicated. After the treatment, the remaining protease activity was assayed in the presence of $2 \mathrm{mM} \mathrm{CaCl}_{2}$. One hundred percent protease activity of the parent and the mutant strains was 2.2 and $2.8 \mathrm{U} / \mathrm{mg}$ of protein, respectively. - parent protease activity with $\mathrm{CaCl}_{2} ; \mathbf{\Delta}$, parent protease activity without $\mathrm{CaCl}_{2} ; \mathrm{C}$, mutant protease activity with $\mathrm{CaCl}_{2} ; \Delta$, mutant protease activity without $\mathrm{CaCl}_{2}$.

was examined in the presence and the absence of $\mathrm{Ca}^{2+}$. As shown in Fig. 5, the activity was similarly inactivated in the two strains by increasing the temperature. A similar heat stability was also found for the extracellular proteases of both strains (data not shown). 
Degradation of preformed proteins in the parent and mutant strains

The degradation of preformed proteins in both parent and mutant strains was examined by using cells labeled with ${ }^{14} \mathrm{C}$ - or ${ }^{3} \mathrm{H}$-amino acid. The preformed proteins were incubated with the crude extracts of the cells and degradation of the labeled proteins was measured. The analytical profiles of the cellular proteins from the parent and mutant strains at mid-logarithmic phase in SDS-polyacrylamide gel electrophoresis were similar (data not shown). When the intracellular proteases were incubated with the cellular proteins labeled with ${ }^{14} \mathrm{C}$ - or ${ }^{3} \mathrm{H}$ amino acid, $30 \%$ of the native protein and $70 \%$ of the denatured protein became acid soluble in 40 min (Fig. 6). From the results shown in Fig. 6, we could not find any difference in substrate proteins and protease activity between the parent and the mutant strains. OKAMURA et al. (3) showed that the degradation of preformed proteins occurred in the parent strain in the stationary phase, while no significant degradation occurred in the mutant strain. They suggested that the protease in the cells was not likely to be functional in the mutant strain during the early stationary phase. As shown in this report, we could not find any difference in proteins and proteases between the parent and the mutant strains, and therefore

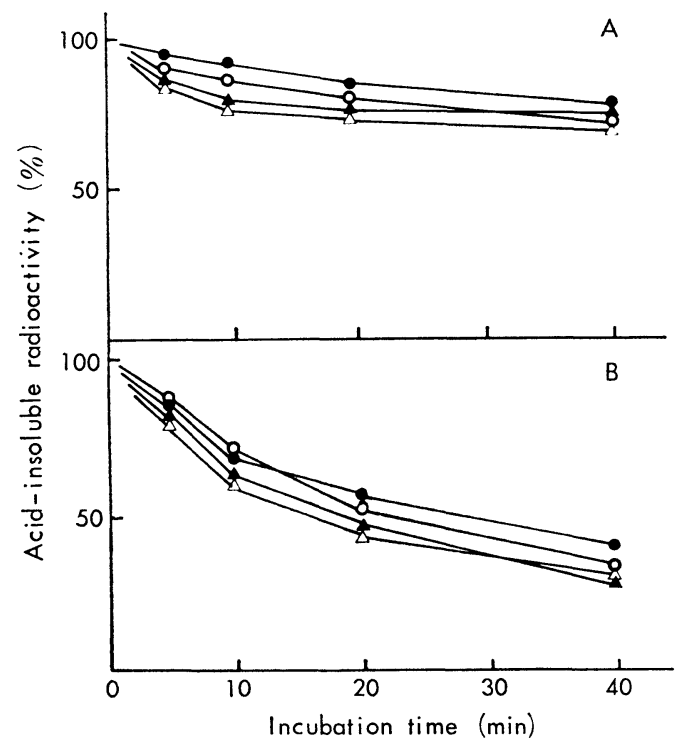

Fig. 6. Digestion of intact (A) and heat-denatured (B) cellular proteins by the intracellular proteases of the parent and mutant strains.

The heat-denatured cellular protein was prepared by incubation at $80^{\circ}$ for $10 \mathrm{~min}$. The enzyme activity was assayed in the presence of $2 \mathrm{mM} \mathrm{CaCl}_{2}$. The parent protease with activity of $2.2 \mathrm{U} / \mathrm{mg}$ of protein and the mutant protease with activity of $2.8 \mathrm{U} / \mathrm{mg}$ of protein were used. $\bullet$, enzyme from the parent, substrate from the parent; $\bigcirc$, enzyme from the parent, substrate from the mutant; $\Delta$, enzyme from the mutant, substrate from the parent; $\triangle$, enzyme from the mutant, substrate from the mutant. 
we speculated that $\mathrm{Ca}^{2+}$, which was specifically required for intracellular protease activity, was not sufficiently available in the mutant strain. Therefore, we next examined the effect of $\mathrm{Ca}^{2+}$ on the growth and sporulation of the two strains.

Effects of calcium ion on growth and spore formation of the parent and mutant strains

Various concentrations of $\mathrm{Ca}^{2+}$ were added to Schaeffer's medium, and growth and spore formation were measured. Higher concentrations of $\mathrm{Ca}^{2+}(500-$ $1,000 \mathrm{mM}$ ) inhibited the growth of both strains and, as shown in Figs. 7A and B, there was no significant difference in the inhibitory effect. As shown in Table 3, maximal spore formation of the parent strain was found at concentrations $o$

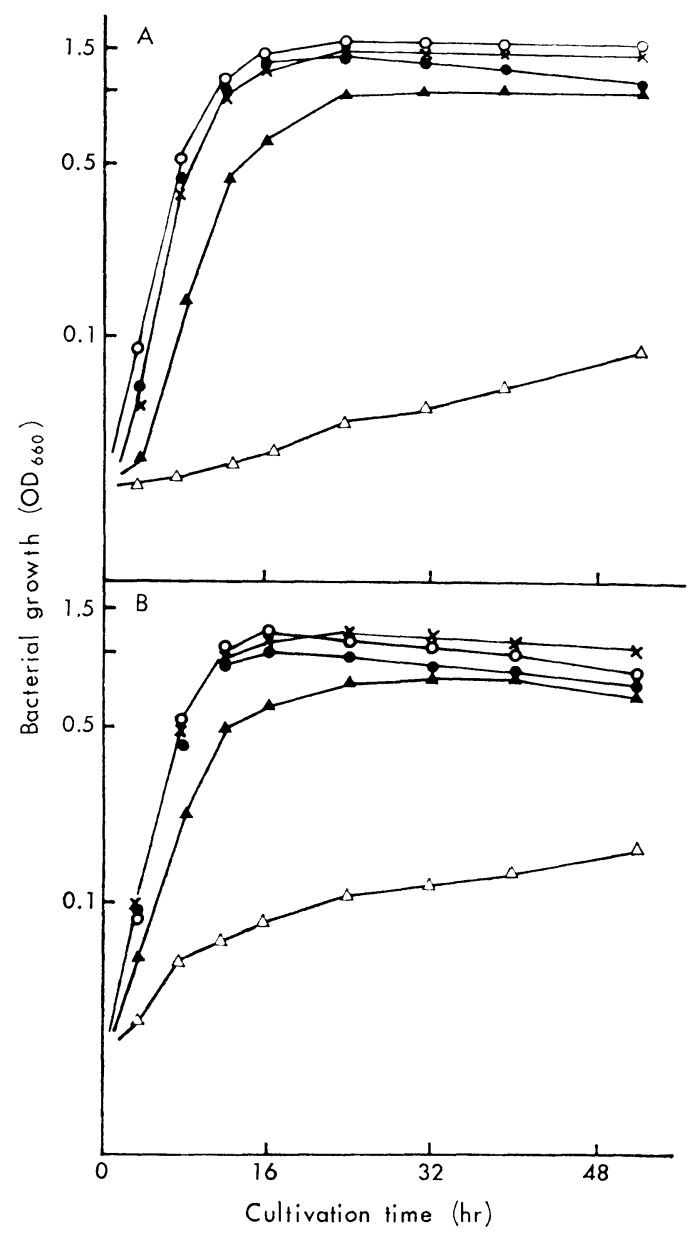

Fig. 7. Growth of the parent (A) and mutant (B) strains at various concentrations of calcium ion.

๑, $0 \mathrm{~mm}$;, $10 \mathrm{~mm} ; \times, 125 \mathrm{~mm} ; \Delta, 500 \mathrm{~mm} ; \Delta, 1,000 \mathrm{~mm}$. 
Table 3. Effect of calcium ions on spore formation.

\begin{tabular}{|c|c|c|}
\hline \multirow{2}{*}{$\begin{array}{c}\mathrm{Ca}^{2+} \text { concentration } \\
(\mathrm{mm})\end{array}$} & \multicolumn{2}{|c|}{ Heat-resistant spores $(\%)$} \\
\hline & Parent & Mutant \\
\hline 0 & $<10^{-6}$ & $<10^{-6}$ \\
\hline 10 & 98 & $<10^{-5}$ \\
\hline 250 & 94 & $<10^{-5}$ \\
\hline 1,000 & 35 & $<10^{-5}$ \\
\hline
\end{tabular}

Both strains were grown in Schaeffer's medium in shaking flasks for $72 \mathrm{hr}$ at $30^{\circ}$. The cell suspension was diluted appropriately and plated on Schaeffer's agar medium for determination of the total viability of the population. A second sample was heated at $80^{\circ}$ for $30 \mathrm{~min}$, then diluted, and plated on the same medium for spore counts.

$\mathrm{Ca}^{2+}$ ranging from $10 \mathrm{~mm}$ to $250 \mathrm{~mm}$. In the parent strain $1,000 \mathrm{mM}$ of $\mathrm{Ca}^{2+}$ was inhibitory, while in the mutant strain no spore formation occurred in the mutant strain at any concentration of $\mathrm{Ca}^{2+}$ examined. Since higher concentration of $\mathrm{Ca}^{2+}$ inhibited the growth of both parent and mutant strains, $\mathrm{Ca}^{2+}$ seems to penetrate normally into the cells. This observation suggests that some defect other than $\mathrm{Ca}^{2+}$ transport may be involved in the mutant.

Uptake of ${ }^{45} \mathrm{Ca}$ into the cells of the parent and mutant strains

As shown in Fig. 8, rapid uptake of ${ }^{45} \mathrm{Ca}^{2+}$ was seen in the culture after $14 \mathrm{hr}$ $\left(T_{5}\right)$, and continued to about $22 \mathrm{hr}$ in the parent strain, while no such uptake was

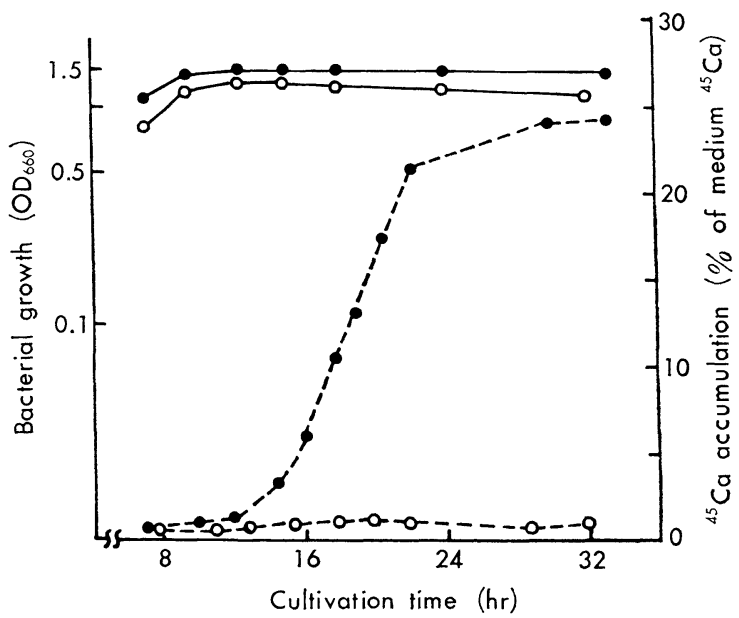

Fig. 8. Calcium accumulation in the parent and mutant strains in the stationary phase.

Calcium accumulation was presented as the ratio (in percent) of cpm of $\mathrm{Ca}^{2+}$ uptake into the cells to the total $\mathrm{cpm}$ of $\mathrm{Ca}^{2+}$ in the medium containing the cells. growth of the parent; - - - growth of the mutant; ------ calcium accumulation of the parent; --- - --- calcium accumulation of the mutant. 
seen in the mutant strain. We speculate that the mutant strain could not accumulate $\mathrm{Ca}^{2+}$ because it could not synthesize dipicolinic acid.

\section{Effect of calcium ion on protein degradation}

The effects of $\mathrm{Ca}^{2+}$ and toluene, which is considered to destroy the barrier of the cell envelope, on protein degradation in Tris- $\mathrm{HCl}$ buffer were examined, with the results shown in Fig. 9. In the case of the parent strain, $2 \mathrm{mM} \mathrm{Ca}^{2+}$ stimulated the rate of protein degradation slightly in the presence of $1 \%$ toluene. In the absence of toluene, no stimulatory effect occurred. We could say that the protein degradation occurred normally without the addition of exogenous $\mathrm{Ca}^{2+}$ in the parent strain. In the mutant strain, on the other hand, no significant degradation of the protein occurred even in the presence of either $\mathrm{Ca}^{2+}$ or toluene. Simultaneous addition of both $\mathrm{Ca}^{2+}$ and toluene, however, increased the protein degradation markedly to the rate comparable with that of the parent strain. From these results, it might be speculated that toluene treatment destroyed the barrier of the envelope of the mutant strain and allowed $\mathrm{Ca}^{2+}$ to penetrate freely into the cells, resulting in the degradation of proteins. It is suggested that the mutant strain is defective in some way in the uptake of $\mathrm{Ca}^{2+}$.

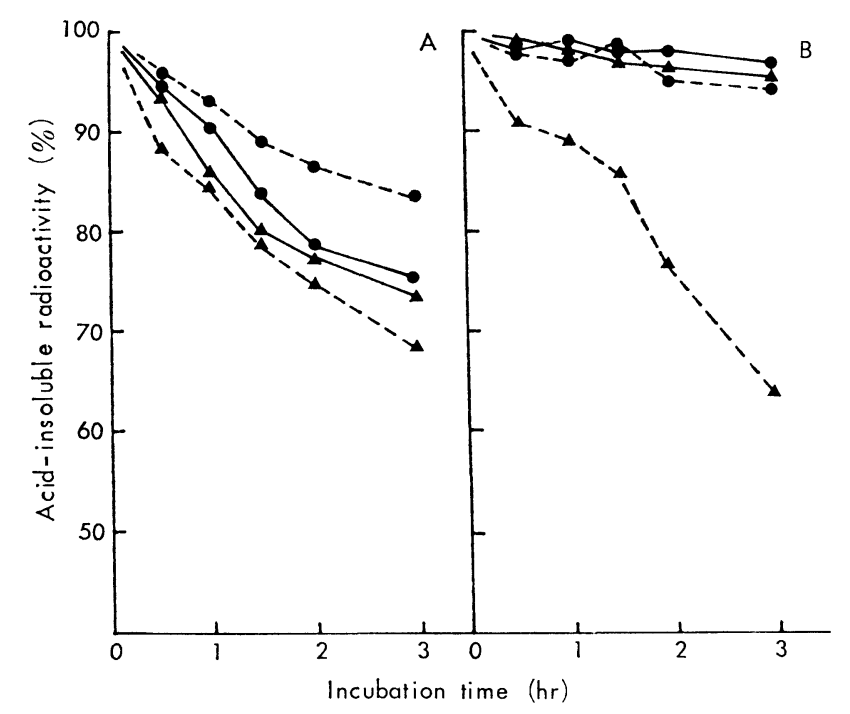

Fig. 9. Protein degradation of the parent (A) and mutant (B) strains in Tris- $\mathrm{HCl}$ buffer.

The cells were resuspended in the four different reaction mixtures at $4^{\circ}$ as described and the reaction was started by shaking at $30^{\circ}$. - - Tris- $\mathrm{HCl}$ buffer alone; Tris- $\mathrm{HCl}$ buffer containing $2 \mathrm{mM} \mathrm{CaCl}_{2} ;$-.-.-.- Tris- $\mathrm{HCl}$ buffer containing $1 \%$ toluene; ---A--- Tris-HCl buffer containing both $2 \mathrm{~mm} \mathrm{CaCl}_{2}$ and $1 \%$ toluene. 


\section{DISCUSSION}

As shown in the previous and present reports, both the parent and mutant strains produce extracellular serine and extracellular metal and intracellular serine proteases. Moreover, the mutant strain produces considerably more proteases than those of the parent strain. Various properties such as $\mathrm{pH}$ optimum, response to metal ions and inhibitors, and heat stability of these proteases from both strains were examined and no significant difference between the two strains was observed. The intracellular protease, which seems to be an important enzyme for sporulation (9-13), was shown to be a serine protease absolutely requiring $\mathrm{Ca}^{2+}$, as shown in other reports $(8,11)$ as well as in our study. We examined in vivo degradation of cellular protein in both the parent and mutant strains by labeling the cells and incubating the cells in Tris-HCl buffer. In agreement with the results of OKAMURA et al.(3), degradation of cellular protein at the stationary phase was detected only in the parent strain.

Electron microscopic study revealed that this mutant was blocked morphologically at stage 0 (unpublished observation) in spite of the production of the intracellular proteases which seem to function from stage 0 (3). This might be supported by the observation that the intracellular protease from the mutant strain is active in vitro but not in vivo. Addition of $\mathrm{Ca}^{2+}$ and toluene together to the reaction mixture of the mutant strain, however, resulted in significant degradation of the cellular protein in the mutant strain although the addition of either $\mathrm{Ca}^{2+}$ or toluene alone had no stimulative effect. No stimulative effect of $\mathrm{Ca}^{2+}$, toluene or the simultaneous addition of $\mathrm{Ca}^{2+}$ and toluene was seen in the case of the parent strain. From these results, it might be speculated that the mutant strain is defective in its transport system for $\mathrm{Ca}^{2+}$. BRONNER et al. $(14,15)$ demonstrated by the Chelex resin method that the $\mathrm{Ca}^{2+}$ binder appears in the early phase of sporulation in $B$. megaterium. Stimulated by these reports, we examined $\mathrm{Ca}^{2+}$ binding activity of the parent and mutant strains using the Chelex resin method or equilibrium dialysis method. So far, no significant difference in the $\mathrm{Ca}^{2+}$ binding activity between the parent and mutant strains has been observed. Although the nature of the $\mathrm{Ca}^{2+}$ binder, which was reported by BRONNER et al. (15), still remains uncertain, our results suggest that $\mathrm{Ca}^{2+}$ transport might regulate an expression of the intracellular serine protease activity responsible for sporulation.

We wish to thank Miss A. Sato for help in the radioassays. This investigation was supported in part by a Grant-in-Aid for Scientific Research from the Ministry of Education, Science and Culture (to K. I. 256070).

\section{REFERENCES}

1) S. Okamura, K. Izaki, and H. Takahashi, J. Gen. Appl. Microbiol., 16, 429 (1970).

2) S. Okamura, K. Izaki, and H. Takahashi, J. Gen. Appl. Microbiol., 17, 215 (1971).

3) S. Okamura, M. Nakamura, K. Izaki, and H. Takahashi, J. Gen. Appl. Microbiol., 21, 
279 (1975).

4) K. T. Yasunobu and J. McConn, In Method of Enzymology, ed. by G. E. Perlmann and L. Lorand, Academic Press, New York (1970), Vol. XIX, p. 569.

5) J. Millet, J. Appl. Bacteriol., 33, 207 (1970).

6) O. H. Lowry, N. J. Rosebrough, A. L. Farr, and R. J. Randall, J. Biol. Chem., 193, 265 (1951).

7) M. KaWAKami and K. Shimura, Radioisotope, 23, 81 (1974).

8) G. Reysset and J. Millet, Biochem. Biophys. Res. Commun., 49, 328 (1972).

9) T. J. Leighton, P. K. Freese, R. H. Doi, R. A. J. Warren, and R. A. Kelln., In Spores V, ed. by O. H. Halvorson, R. Hanson, and L. L. Campbell, American Society for Microbiology, Washington, D. C. (1972), p. 238.

10) J. H. Hageman and B. C. Carlton, J. Bacteriol., 114, 612 (1973).

11) J. Szulmajster and E. Keryer, In Spores VI, ed. by P. Gerhardt, R. N. Costilow, and H. L. SADoff, American Society for Microbiology, Washington, D. C. (1975), p. 271.

12) Y. E. Cheng and A. I. Aronson, Proc. Natl. Acad. Sci. U. S., 74, 1254 (1977).

13) B. N. Dancer and J. Mandelstam, J. Bacteriol., 121, 406 (1975).

14) F. Bronner and T. S. Freund, In Spores V, ed. by H. O. Halvorson, R. Hanson, and L. L. Campbell, American Society for Microbiology, Washington, D. C. (1972), p. 187.

15) F. Bronner, W. C. Nash, and E. E. Golub, In Spores VI, ed. by P. Gerhardt, R. N. Costilow, and H. L. SAdoff, American Society for Microbiology, Washington, D. C. (1975) p. 356 . 